\title{
PENGARUH TINGKAT ADOPSI INOVASI \\ TERHADAP TINGKAT PENDAPATAN USAHATANI DAN PENDAPATAN TOTAL PETANI TRANSMIGRAN LOKAL
}

(Suatu Kasus di Wilayah Transmigrasi Umum Sabung SP 1

Kabupaten Sambas Provinsi Kalimantan Barat)

Oleh

AGUS WARMAN

Program Doktor Ilmu Pertanian Universitas Padjadjaran

Email: dr.aguswarman@yahoo.co.id

\begin{abstract}
Abstrak
Salah satu upaya untuk meningkatkan kesejahteraan petani ladang berpindah adalah dengan cara mengubah pola pertanian mereka menjadi pola pertanian menetap di lokasi transmigrasi. Tujuan penelitian adalah : Mengetahui pencapaian adopsi inovasi teknologi oleh petani transmigran lokal dan pengaruhnya terhadap tingkat pendapatan usahatani dan pendapatan total mereka Penelitian ini merupakan kasus di lokasi Transmigrasi Sabung SP 1 Kabupaten Sambas Provinsi Kalimantan Barat. Merupakan penelitian survey dan alat analisis yang digunakan adalah Path Analisis dan Uji Wilcoxon. Hasil penelitian mendapatkan bahwa Tingkat adopsi inovasi transmigran lokal berpengaruh terhadap tingkat pendapatan usahatani, namun tidak berpengaruh terhadap tingkat pendapatan total mereka. Tingkat pendapatan total mereka setelah mengikuti program transmigrasi lebih besar dibanding sebelum mengikuti transmigrasi.
\end{abstract}

Kata kunci : perubahan pola pertanian, transmigran lokal, tingkat adopsi inovasi, tingkat pendapatan usahatani, tingkat pendapatan total

\section{PENDAHULUAN}

Michael R. Dove (1985), menyimpulkan bahwa sistem perladangan merupakan hasil adaptasi paling baik dan paling rasional yang dilakukan masyarakat adat, terhadap lingkungan alam dan sosialnya. Apa yang dikemukakan oleh Michael R. Dove di atas adalah realistis ketika kondisi daya dukung luasan lahan yang tersedia, relatif cukup tinggi dibanding kebutuhan luasan lahan yang dibutuhkan oleh penduduk desa hutan bagi kegiatan perladangan berpindahnya. Pada kondisi saat ini, di Indonesia khususnya, terjadi kecenderungan dimana jumlah penduduk desa hutan terus meningkat jumlahnya, namun di sisi lain justru terjadi penyempitan jumlah luasan lahan hutan yang dapat dikuasai untuk kegiatan perladangan mereka.

Menurut data Kementrian Negara Percepatan Pembangunan Daerah Tertinggal (PDT), di Indonesia saat ini terdapat 18.782 desa hutan atau sekitar 26,6\% dari total seluruh desa yang ada di Indonesia, atau sebesar 58\% dari jumlah total desa tertinggal yang ada di Indonesia (32.379 desa tertinggal). Jumlah total penduduknya mencapai 33.512.845 jiwa. Dari jumlah total penduduk desa hutan tersebut, jumlah keluarga yang menggantungkan 100\% sumber bahan pangan melalui perladangan dan ekstraktif dari kawasan hutan adalah sebanyak 848.575 KK, $45 \%$ diantaranya masuk dalam kategori keluarga miskin (Krisnadi : 2010).

Terjadinya kondisi peningkatan jumlah penduduk dan makin menyempitnya luasan lahan yang dapat "dikuasai" untuk kegiatan perladangan padi, dialami juga antara lain oleh masyarakat Dayak di Propinsi Kalimantan Barat. Sejak ratusan tahun lalu, masyarakat dayak yang bermukim di kawasan hutan Kalimantan Barat telah mengembangkan sistem distribusi sumber daya alam, ekonomi dan politik berdasarkan hukum adat. Komunitas suku-suku adat dayak terhimpun dalam suatu komunitas Binua atau kampong yang bersifat Self governing community, dimana memiliki otonomi pengelolaan luasan hutan sendiri, bagi kepentingan pemenuhan setiap anggota komunitasnya, yang dikenal dengan istilah lahan Ulayat. Pada kondisi masih terakuinya lahan hutan ulayat sebagai lahan milik komunitas Binua, luasan lahan ulayat masih memungkinkan untuk digunakan oleh penduduk untuk kegiatan perladangan padi dengan rotasi penggunaan lahan perladangan dengan masa bera 10 - 15 tahun (Benyamine, 2009).

Binua atau kampong sebagai Self governing community hancur semenjak 


\section{AIMBAR \\ A GRIBISNIS}

ISSN 2460-4321

Volume 1・ Nomor 1 • Juli 2015

pemberlakuan UU Nomor 5 Tahun 1979, dimana binua-binua atau kampong-kampong digabungkan menjadi desa administratif. Tanah hutan ulayat yang sejak ratusan tahun lalu menjadi milik komunitas binua diklaim sebagai tanah negara, dan hak komunitas binua untuk memiliki dan mengelola sumberdaya alam di sekitarnya menjadi hilang. Tanah hutan ulayat kemudian diserahkan pengelolaannya pada para pemegang $\mathrm{HPH}$, sehingga dengan demikian luasan lahan hutan yang biasa dijadikan kawasan perladangan berpindah menjadi jauh menyempit. Akibatnya, rotasi masa bera antara satu lahan dengan lahan lainnya yang biasa digunakan oleh masyarakat menjadi semakin singkat, yaitu berkisar antara $3-5$ tahun (Edi Petebang, 1999).

Jumlah luasan perladangan padi di Kalimantan Barat menurut data BPS (2010) adalah $105.405 \mathrm{Ha}$, dan menurut penelitian Ikhrosnaeni (2006), rerata lahan perladangan padi yang diusahakan per KK oleh masyarakat desa Hutan di Kalimantan Barat dalam kegiatan ladang berpindah adalah seluas 1,12 Ha. Ini artinya, di Kalimantan Barat setidaknya ada sekitar 94.112 KK petani padi yang menggandalkan sumber makanan pokok keluarga mereka dari kegiatan ladang berpindah.

Terdapatnya dua kondisi yang saling kontra produktif, yang dihadapi khususnya oleh petani peladang berpindah di Kalimantan Barat, yaitu makin menyempitnya luasan lahan yang bisa digunakan untuk kegiatan perladangan padi sebagai sumber makanan pokok di satu sisi, dan kondisi semakin meningkatnya pertumbuhan penduduk di sisi lain, merupakan dua kondisi ancaman bagi ketahanan pangan pokok keluarga mereka. Ketahanan pangan pokok keluarga, (sejalan dengan pengertian menurut PP Nomor 28 tahun 2002 tentang ketahanan pangan), dalam hal ini diartikan sebagai "Kondisi terpenuhinya pangan pokok (beras) bagi rumah tangga petani, yang tercermin dari tersedianya pangan pokok yang cukup dalam hal jumlah dan mutunya“. Keterancaman ketahanan pangan pokok mereka akan semakin meningkat di masa mendatang, jika ternyata kondisi-kondisi yang berkaitan dengan peladang berpindah, tiada kunjung mengalami perubahan ke arah lebih baik dari kondisi saat ini.
Memperhatikan besarnya jumlah desa hutan dan jumlah penduduknya yang berstatus sebagai peladang berpindah ternyata relatif cukup banyak di Indonesia, dimana jumlah dari mereka juga banyak terkategorikan sebagi penduduk miskin di satu sisi, maka salah satu alternatif untuk menanggulanginya adalah melalui "program pembinaan intensif pada keluarga petani peladang berpindah", dalam bentuk program transformasi pola perladangan berpindah ke program pembinaan pola usahatani lahan menetap".

Walaupun sifatnya bukanlah sebagai program yang ditujukan khusus untuk mentransformasikan kegiatan perladangan berpindah menjadi pola perladangan menetap, namun salah satu bentuk program pemerintah yang mengarah pada upaya transformasi dari keluarga petani di Kalimantan Barat, yang awalnya menerapkan pola perladangan berpindah menjadi petani pola ladang menetap adalah "Program Transmigrasi Penduduk Setempat (TPS)", yang merupakan bagian dari Program Transmigrasi Umum (PTU). Pada Program Transmigrasi Umum ini, petani peserta program bukan melulu berasal dari luar propinsi, namun juga memasukkan peserta transmigrasi yang berasal dari penduduk lokal. Khususnya di Kalimantan Barat, penduduk setempat yang dimaksudkan tersebut diantaranya adalah para penduduk suku dayak dan suku melayu pedalaman yang awalnya berprofesi sebagai petani peladang berpindah. Salah satu lokasi transmigrasi umum yang diselenggarakan di Kalimantan Barat adalah di lokasi permukiman transmigrasi Sabung SP 1 yang berada di wilayah administrasi Kabupaten Sambas.

Salah satu tujuan yang ingin dicapai dari diselenggarakannya program transmigrasi adalah upaya peningkatan kesejahteraan petani transmigran, baik kesejahteraan secara objektif (Kesejahteraan materiil yang diukur secara objektif antara lain berdasarkan tingkat pendapatan), maupun kesejahteraan Non materil (yang diukur secara subjektif antara lain berdasarkan tingkat kepuasan terhadap hal-hal non pangan para transmigran), antara lain kepuasan para transmigran terhadap kondisi fasilitas rumah dan lahan, fasilitas pendidikan, fasilitas kesehatan, fasilitas penerangan, 
fasilitas prasarana transportasi dan kondisi ketentraman dalam interaksi sosial).

Berdasarkan tujuan program transmigrasi tersebut, maka adalah penting untuk meneliti sejauhmana dampak perubahan pola usahatani para transmigran lokal dari pola usahatani perladangan menjadi pola usahatani pertanian menetap di lokasi transmigrasi, terhadap perubahan tingkat kesejahteraan mereka antara sebelum mengikuti dan setelah mengikuti program transmigrasi.

\section{TINJAUAN PUSTAKA}

Tingkat Kesejahteraan seseorang atau sekelompok masyarakat dapat diukur menurut kategori yang berkaitan dengan konsep tingkat kemiskinan. Menurut Lokshin dan Ravallion dalam Suandi dan Damayanti (2010), pengertian kesejahteraan dilihat dari dua pendekatan, yakni : "kesejahteraan Objektif" dan "kesejahteraan Subjektif". Kesejahteraan objektif adalah tingkat kesejahteraan individu atau kelompok masyarakat yang diukur secara rata-rata dengan patokan tertentu, baik ukuran ekonomi, sosial maupun ukuran lainnya, Dengan kata lain, tingkat kesejahteraan seorang individu atau kelompok masyarakat diukur dengan pendekatan yang baku. Salah satu ukuran kesejahteraan secara objektif antara lain yaitu diukur menurut kategori tingkat kemiskinan yang dikemukakan oleh Zulkifli Husin dalam Supriatna (1997), yaitu bisa dilakukan dengan menggunakan Rasio Kebutuhan Fisik Minimum sesuai dengan kondisi yang dihadapi saat ini, maka jika diumpamakan untuk memenuhi kebutuhan hidup empat sehat lima sempurna per kapita per hari adalah Rp. 2.500, maka dapat ditentukan nilai kebutuhan fisik minimum per tahun yaitu sebesar Rp. $2.500 \times 365$ hari $=$ Rp. 912.500. Apabila nilai kebutuhan fisik minimum per kapita per tahun ini dijadikan sebagai pembagi, maka akan diperoleh Rasio Kebutuhan Fisik Minimum (R-KFM). Dari hasil perhitungan tersebut dapat dikategorikan apakah penduduk tersebut miskin atau tidak. Jika nilai R-KFM yang diperoleh sama dengan satu, berarti penduduk tersebut dikategorikan sebagai penduduk miskin, karena tingkat pendapatannya setingkat dengan tingkat subsisten (subsistance level). Artinya, pendapatan yang diperoleh orang tersebut hanya cukup untuk mempertahankan hidup. Formulasi pengkategorian tingkat kemiskinan berdasar R-KFM adalah :

$\mathrm{R}-\mathrm{KFM} \leq 0,75 \rightarrow$ Miskin sekali

R-KFM 1,01 - 1,50 $\rightarrow$ Nyaris Miskin

R-KFM 0,76-1,00 $\rightarrow$ Miskin

R-KFM 1,51 - 2,00 $\rightarrow$ Nyaris Kaya

Adapun kesejahteraan subjektif, adalah tingkat kesejahteraan seorang individu yang dilihat secara personal, dan diukur dalam bentuk kepuasan dan kebahagiaan. Menurut hasil penelitian Sumarti (1999) dalam Suandi dan Damayanti (2010), kesejahteraan subjektif individu atau keluarga adalah wujud kebudayaan yang dihasilkan melalui proses pengalaman hidup sekelompok manusia dalam hubungannya dengan lingkungan (fisik dan sosial). Artinya, pengertian kesejahteraan haruslah berpedoman pada subjektivitas masyarakat setempat (lokal). Menurut Angel, dan Black Well, dan Miniard (Sumarwan, 2003), kesejahteraan subjektif diukur dalam bentuk kepuasan, dimana " satisfaction is defined here as past consumption evaluation that a chosesn alternative at least meets or exeeds expectation" (kepuasan merupakan hasil evaluasi dari konsumsi yang lalu sehingga alternatif yang dipilih paling tidak sesuai dengan kriteria atau melebihi krteria yang diharapkan).

Pengukuran kesejahteraan secara subjektif, antara lain dilakukan berdasar tolak ukur kepuasan terhadap : (1) Pemenuhan kebutuhan pangan, (2) Pemenuhan kebutuhan Non Pangan, dan (3) Pemenuhan investasi Sumberdaya manusia.

Kepuasan pemenuhan kebutuhan non pangan, diukur dari kepuasan pemenuhan akan sandang/pakaian, papan/perumahan, energi, prasarana dan sarana komunikasi/transportasi, serta pemenuhan kebutuhan sosial/kemasyarakatan. Sedangkan kepuasan terhadap pemenuhan kebutuhan investasi SDM keluarga, dapat diukur dari kepuasan terhadap pemenuhan kebutuhan akan biaya pendidikan dan biaya kesehatan. ( Suandi dan Damayanti, 2010). Kebutuhan sosial/kemasyarakatan menurut Sudjarwo (1997) antara lain berkaitan dengan tingkat keharmonisan interaksi sosial antara individu satu dengan individu lain, individu dengan kelompok atau kelompok satu dengan kelompok lainnya. Tingkat 


\section{MIMBAR \\ A GRIBISNIS \\ ISSN 2460-4321}

Volume 1・Nomor 1・Juli 2015

keharmonisan interaksi sosial ini terlihat dari rentang jarak sosial yang terjadi di masyarakat, dimana rentang sosial ini akan dipengaruhi oleh sikap yang terjadi antara satu komponen mansyarakat satu dengan komponen masyarakat lainnya.

Keberhasilan upaya peningkatan kesejahteraan materil para petani dapat diukur melalui tingkat pendapatan yang bisa dicapai oleh para petani tersebut. Tingkat pendapatan petani akan ditentukan terutama dari sejauhmana keberhasilan pembangunan pertanian dapat tercapai di wilayah mereka. Menurut teori klasik yang dikemukakan oleh Mosher A.T (1966), pembangunan pertanian di suatu wilayah akan ditentukan oleh sejauhmana ketersediaan faktor mutlak dan faktor pelancar usahatani. Faktor mutlak mencakup : Adanya inovasi teknologi usahatani yang terus menerus, ketersediaan sarana produksi saat diperlukan petani, tersedianya pasar hasil usahatani, adanya harga produksi yang menguntungkan petani, tersedianya sarana dan prasarana pengangkutan. Adapun faktor pelancar diantaranya adalah : Adanya pendidikan inovasi teknologi bagi petani (melalui penyuluhan), ketersediaan kredit usahatani, serta adanya perbaikan kondisi lahan usahatani. Selain hal di atas, menurut Sai'd (2001), faktor input tenaga kerja merupakan hal penting dalam proses produksi usahatani.

Kerangka pemikiran dalam penelitian ini dapat dideskripsikan sebagai berikut.

Tujuan akhir yang ingin dicapai dari pelaksanaan program transmigrasi adalah peningkatan kualitas kesejahteraan para transmigran, terutama transmigran yang berasal dari penduduk setempat/lokal. Kesejahteraan yang dimaksudkan yaitu mencakup kesejahteraan materil dan non materil.

Kesejahteraan materil petani transmigran sangat ditentukan oleh kondisi tinggi-rendahnya pendapatan dari hasil usahatani mereka, pada lahan usahatani dan lahan pekarangan yang disediakan oleh pemerintah di lokasi transmigrasi. Faktor utama yang menjadi penentu keberhasilan petani dalam usahatani mereka adalah tingkat adopsi inovasi oleh petani itu sendiri. Tingkat adopsi ini dipengaruhi oleh kondisi variabel-variabel : (1) Kualitas serapan inovasi dari penyuluh ; (2) Kualitas serapan inovasi teknologi dari petani lain; (3) Potensi TK dan Modal Keluarga; (4) Ketersediaan saprodi, kredit usahatani, dan pasar hasil usahatani. Tinggi rendahnya tingkat adopsi inovasi teknologi oleh petani ini akan menentukan tingkat produksi yang mereka capai, dan ini berkorelasi terhadap tingkat pendapatan mereka.

Kesejahteraan Non materil petani transmigran dipengaruhi oleh dua kondisi utama, yaitu aspek kepuasan terhadap prasarana dan sarana yang bisa mereka peroleh di lokasi transmigrasi, serta aspek keharmonisan interaksi sosial yang tercipta diantara sesama petani dalam kehidupan keseharian. Khususnya berkaitan dengan aspek interaksi sosial antar petani transmigran setempat dan transmigran pendatang, kondisinya akan dapat diukur dari sejauhmana jarak sosial yang terjadi diantara mereka. Renggang atau tidaknya jarak sosial yang terjadi diantara mereka tergantung pada faktor sikap petani/kelompok petani satu terhadap petani/kelompok petani lainnya. Terbentuknya jenis sikap ini sangat dipengaruhi oleh latar belakang budaya petani/kelompok petani bersangkutan. Secara visual jalinan antar variabel ini terlihat dari paradigma penelitian pada Gambar 1.

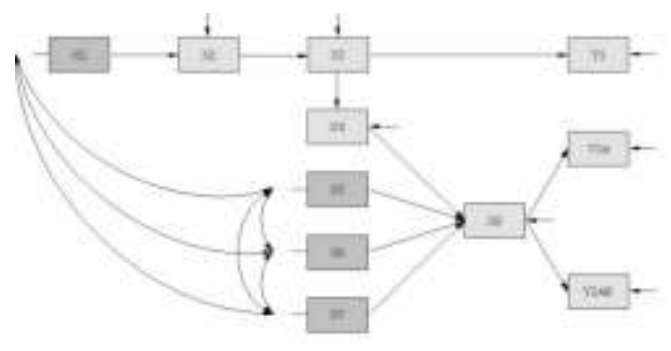

Gambar 1. Diagram Konseptual Hubungan
Struktural Antar Variabel.

Keterangan :

$\mathrm{X}_{1}=$ Sikap Terhadap Etnis Lain.

$\mathrm{X}_{2}=$ Rentang Jarak Sosial.

$\mathrm{X}_{3}=$ Keharmonisan Interaksi Sosial.

$\mathrm{X}_{4}=$ Serapan Inovasi dari Sesama Petani.

$\mathrm{X}_{5}=$ Sikap Petani terhadap Kegiatan Penyuluhan.

$\mathrm{X}_{6}=$ Kondisi Internal Petani.

$\mathrm{X}_{7}=$ Ketersediaan Lembaga Pendukung Usahatani.

$\mathrm{X}_{8}=$ Tingkat Adopsi Inovasi teknologi usahatani.

$\mathrm{Y}_{1}=$ Tingkat Kepuasan Petani terhadap Kondisi

Fasilitas dan Lingkungan Sosial.

$\mathrm{Y}_{2 \mathrm{~A}}=$ Pendapatan dari Usahatani Milik Sendiri.

$\mathrm{Y}_{2 \mathrm{AB}}=$ Tingkat Pendapatan Total . 


\section{AGUS WARMAN}

\section{Hipotesis}

Berdasar pada tinjauan pustaka dan proposisi-proposisi yang diuraikan pada kerangka pikir di atas, maka dua proposisi sebagai hipotesis yang perlu diuji kebenarannya dalam penelitian ini adalah :

$\mathrm{H}_{1}=$ Tingkat Penerapan/ adopsi inovasi mempengaruhi tingkat pendapatan usahatani petani transmigran lokal/ tingkat kesejahteraan materil petani dari usahatani di lokasi transmigrasi.

$\mathrm{H}_{1}=$ Tingkat Penerapan/ adopsi inovasi mempengaruhi tingkat pendapatan total petani transmigran lokal.

\section{METODE PENELITIAN}

Objek utama penelitian adalah petani peladang berpindah yang mengikuti program transmigrasi umum di wilayah transmigrasi umum Sabung SP 1 di kabupaten Sambas Propinsi Kalimantan Barat. Pemilihan lokasi dilakukan secara purposive dengan pertimbangan lokasi transmigrasi umum tersebut baru berjalan sekitar 4 tahun, berarti masih dalam masa pembinaan penuh dari pihak Departemen Tenaga Kerja dan Transmigrasi.

Metode yang digunakan dalam penelitian ini adalah metode survei. Menurut Singarimbun dan Effendi (1987), penelitian survei adalah penelitian yang mengambil sampel dari populasi dengan menggunakan kuesioner sebagai alat bantu pengumpulan data.

Penelitian ini bersifat deskriptif eksplanatoris. Deskriptif bertujuan untuk memperoleh gambaran secara sistematis, faktual dan akurat mengenai fakta-fakta, sifatsifat serta hubungan dari variabel yang diteliti. Eksplanatoris bertujuan untuk mengetahui hubungan kausal antar variabel dalam hipotesis. (Kuswantinah, 2005). Indept study melalui observasi langsung, observasi partisipasi dan wawancara bebas, juga dilakukan dalam penelitian ini untuk memperdalam pemahaman atas permasalahan yang diteliti, guna membahas fenomena yang sulit didekati secara kuantitatif.

Jumlah seluruh populasi petani transmigran lokal adalah $125 \mathrm{KK}$. Penentuan ukuran sampel petani dilakukan dengan menggunakan rumus ukuran sampel minimum dari Slovin dalam Paturochman (2012) sebagai berikut :

$$
\mathrm{n}=\frac{\mathrm{N}}{\mathrm{Ne}^{2}+1}
$$

Dimana :

$\mathrm{n} \quad=$ Ukuran sampel petani

$\mathrm{N}=$ Ukuran Populasi petani.

$\mathrm{e} \quad=$ Presisi yang diinginkan $(95 \%) /$ tingkat kesalahan yang ditolerir $(5 \%)$

1 = Angka konstanta.

Berdasar rumus ukuran sampel minimal di atas, maka ukuran sampel minimal dalam penelitian ini adalah :

$$
\mathrm{n}=\frac{125}{125(0,05)^{2}+1}=77 \mathrm{KK}
$$

Pengambilan data dilakukan dengan alat bantu kuesioner, menggunakan skala Likert dengan hasil data mentah berupa data ordinal. Metode analisis data yang digunakan adalah analisis jalur (Path Analysis), menggunakan program LISREL. Analisis jalur merupakan bagian dari statistika parametrik yang digunakan untuk menganalisis data interval atau rasio (Sugiyono, 2007) yang mengasumsikan adanya distribusi normal. Untuk keperluan tersebut, maka data yang berskala ordinal ditransformasikan terlebih dahulu ke dalam skala interval melalui Method of successive interval (MSI). Untuk melihat tingkat signifikansi perbedaan tingkat pendapatan petani lokal dari usahatani antara sebelum dan sesudah mengikuti program transmigrasi digunakan Uji beda Wilcoxon.

\section{HASIL DAN PEMBAHASAN \\ Pengaruh Tingkat Adopsi Teknologi Usahatani terhadap Tingkat Pendapatan Petani Transmigran Lokal dari Usahatani.}

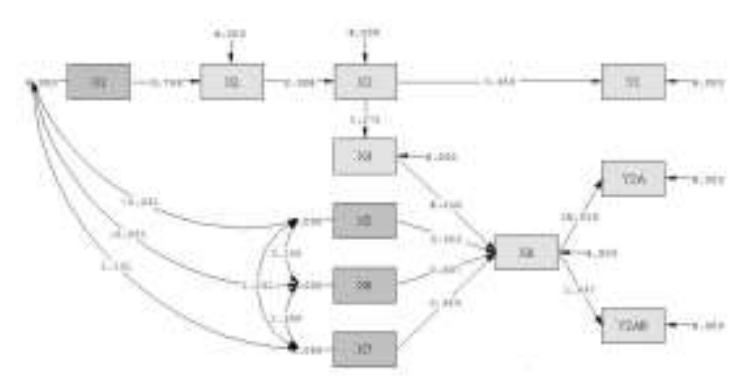

Gambar 7. Diagram Nilai t Pengaruh X8 Terhadap Y2A 


\section{MIMBAR \\ A GRIBISNIS \\ ISSN 2460-4321}

Volume 1・Nomor 1・Juli 2015

Berdasarkan hasil estimasi yang disajikan melalui gambar diagram di atas diketahui bahwa nilai $t_{\text {hitung }}$ pengaruh $\mathrm{X} 8$ terhadap $\mathrm{Y} 2 \mathrm{~A}$ adalah sebesar 16,014. Dengan taraf signifikansi $(\alpha)$ sebesar 0,05 dan derajat bebas sebesar $n-k-1=77-1-1=75$ didapat nilai $t_{\text {tabel }}$ dari tabel distribusi t dua pihak sebesar 1,992. Dikarenakan nilai mutlak $t_{\text {hitung }}$ lebih besar dari nilai $t_{\text {tabel }}(|16,014|>1,992)$, maka dapat disimpulkan bahwa secara statistik, pengaruh X8 terhadap Y2A tersebut signifikan.

Hasil uji statistik di atas khususnya berkaitan dengan Hipotesis keenam, dimana berdasar hasil uji statistik di atas maka dapat dideskripsikan hal-hal sebagai berikut :

1. Perubahan yang terjadi pada Tingkat adopsi inovasi petani transmigran lokal berpengaruh secara nyata terhadap perubahan tingkat pendapatan usahatani mereka (Tolak $\mathrm{H}_{0}$ dan Terima $\mathrm{H}_{1}$ ).

2. Perubahan yang terjadi pada Tingkat adopsi inovasi petani transmigran lokal berbanding lurus dengan perubahan tingkat pendapatan dari usahatani mereka.

3. Tingkat adopsi inovasi transmigran lokal menentukan tingkat tingkat pendapatan usahatani petani transmigran lokal sebesar $78,15 \%$, sedangkan sisanya sebesar $21,85 \%$ merupakan kontribusi variabel lain yang tidak diamati di dalam sub struktur 7 model analisis jalur penelitian ini.

\section{Pengaruh Tingkat Adopsi Teknologi Usahatani terhadap Pendapatan Total Petani Transmigran Lokal.}

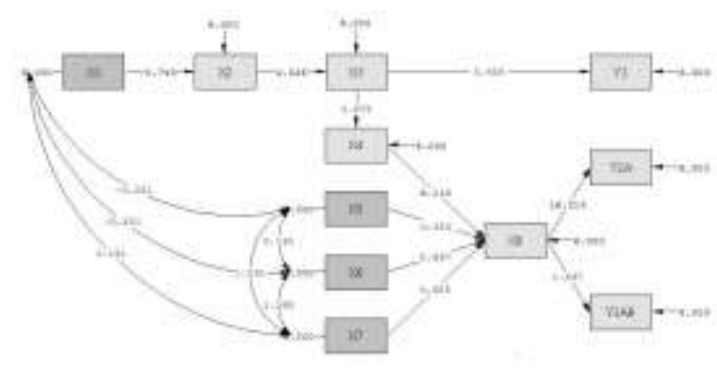

Gambar 8. Diagram Nilai t Pengaruh X8 Terhadap Y2AB

Berdasarkan hasil estimasi yang disajikan melalui gambar diagram di atas diketahui bahwa nilai $t_{\text {hitung }}$ pengaruh $\mathrm{X} 8$ terhadap $\mathrm{Y} 2 \mathrm{AB}$ adalah sebesar 1,447 . Dengan taraf signifikansi $(\alpha)$ sebesar 0,05 dan derajat bebas sebesar n-k-1 $=77-1-1=75$ didapat nilai $t_{\text {tabel }}$ dari tabel distribusi $t$ dua pihak sebesar 1,992. Dikarenakan nilai mutlak $t_{\text {hitung }}$ lebih kecil dari nilai $\mathrm{t}_{\text {tabel }}(|1,447|<1,992)$, maka dapat disimpulkan bahwa secara statistik, pengaruh X8 terhadap Y2AB tersebut tidak signifikan.

Hasil uji statistik di atas khususnya berkaitan dengan Hipotesis ketujuh, dimana berdasar hasil uji statistik di atas maka dapat dijelaskan hal-hal sebagai berikut:

1. Perubahan yang terjadi pada Tingkat adopsi inovasi petani transmigran lokal tidak berpengaruh secara nyata terhadap perubahan tingkat pendapatan total mereka (Terima $\mathrm{H}_{0}$ dan Tolak $\mathrm{H}_{1}$ ). Hal ini dimungkinkan karena saat ini pendapatan total petani transmigran lokal lebih banyak bersumber dari non usahatani dibanding dari hasil usahatani mereka di lokasi transmigrasi. Hal ini terlihat dari kenyataan bahwa Tingkat adopsi inovasi transmigran lokal hanya menentukan tingkat pendapatan usahatani petani transmigran lokal sebesar $2,82 \%$, sedangkan sisanya sebesar 97,18\% merupakan kontribusi variabel lain, yang dalam hal ini variabel penentu tersebut kemungkinan besar adalah ditentukan oleh pendapatan mereka di luar usahatani atau non usahatani di luar lokasi transmigrasi.

2. Perubahan yang terjadi pada Tingkat adopsi inovasi petani transmigran lokal berbanding lurus dengan perubahan tingkat pendapatan dari usahatani mereka. Artinya, walaupun peran adopsi inovasi petani transmigran lokal sedikit pengaruhnya terhadap besar kecilnya pendapatan total mereka, namun kenaikan pendapatan dari usahatani akan turut meningkatkan pendapatan total mereka, dan sebaliknya.

Untuk mengetahui signifikansi pendapatan usahatani petani transmigran lokal antara sebelum dan sesudah mengikuti program transmigran, dilakukan dengan Uji beda menggunakan Test Wilcoxon, dimana ternyata terdapat perbedaan yang signifikan antara pendapatan usahatani sebelum mengikuti program transmigrasi dan setelah mengikuti program transmigrasi. 
Pengaruh Tingkat Adopsi Inovasi Terhadap Tingkat Pendapatan Usahatani dan Pendapatan Total

Petani Transmigran Lokal (Suatu Kasus di Wilayah Transmigrasi Umum Sabung SP 1

Kabupaten Sambas Provinsi Kalimantan Barat)

AGUS WARMAN

\section{PENUTUP}

Pertama: Tingkat adopsi inovasi transmigran lokal berpengaruh nyata terhadap tingkat pendapatan usahatani mereka.

Kedua: Tingkat adopsi inovasi transmigran lokal tidak berpengaruh nyata terhadap tingkat pendapatan total mereka, hal ini antara lain karena proporsi tingkat pendapatan dari non usahatani jauh lebih tinggi daripada tingkat pendapatan dari usahatani.

\section{DAFTAR PUSTAKA}

Abustam, Muhammad Idrus. 1990. Gerak Penduduk, Pembangunan dan Perubahan Sosial. Jakarta : UI Press.

Akib Tuwo, M. 2001. Alokasi Sumberdaya dan Faktor Sosial Ekonomi yang Mempengaruhi Penerapan Teknologi Serta Hubungannya dengan Kualitas Hidup Petani. Disertasi Doktor, Program Pascasarjana Universitas Padjadjaran, Bandung (Tidak dipublikasikan).

Azwar, Syaifuddin, 1995. Sikap Manusia Teori dan Pengukurannya. Yogyakarta: Pustaka Pelajar.

Baruadi, Rudin .1993. Faktor-faktor yang mempengaruhi Sikap dan Adopsi Petani Terhadap Modernisasi Pertanian Padi Sawah dan Petani Tambak di Sulawesi

Selatan, Disertasi Doktor, Pascasarjana, Universitas Padjadjaran. (Tidak dipublikasikan).

Bayo Ala, Andre. 1996. Kemiskinan dan Strategi Memerangi Kemiskinan. Yogyakarta : Liberty.

Benyamine, M. 2009. Reinkarnasi Tanah Hak Ulayat Masyarakat Dayak Kalimantan Barat. Materi Seminar Kearifan Lokal Masyarakat Adat. Pontianak: Universitas Tanjungpura.

Fliegel, F. C., J. E. Kivlin and G. S. Sekhon.1977. Message Distorsion and Diffusion of Innovation in Northern India. New Delhi : Sociologis Nuralis.

Hair, J.F., Anderson, R.E., Tatham, R.L., dan Black, W.C., 1998. Multivariate Data Analysis (5 $5^{\text {th }}$ Edition), UK: Prentice Hall International.

Ikrosnaeni, S. 2006. Pendapatan Petani Ladang Berpindah di Sekitar Hak Pengusahaan Hutan PT. Suka Jaya Makmur Kalimantan Barat. Thesis, Departemen Manajemen
Hutan Fakultas Kehutanan IPB (Tidak dipublikasikan).

Krisnadi, Johan. 2010. Beberapa Kendala dalam Upaya Peningkatan Taraf Hidup Masyarakat Desa Hutan di Kalimantan Barat. Materi Seminar. Pontianak: Universitas Tanjungpura.

Kusnendi, 2007. Model-model Persamaan Struktural Satu dan Multigroup Sampel Dengan LISREL. Bandung: Alfabeta.

Kuswandie. 2010. Praktek Pertanian Ladang Berpindah di Kecamatan Nanga Ketungau Kabupaten Sintang Provinsi Kalimantan Barat. Laporan Penelitian. Sintang : LSM Gema Rasa.

Kuswantinah. 2005. Hubungan Antara Produktivitas dan Luas Lahan dengan Pendapatan Petani Kentang di Pagar Alam Provinsi Sumatera Selatan. Disertasi

Doktor, Program Pascasarjana Universitas Padjadjaran, Bandung (Tidak dipublikasikan).

Land, Kenneth C., 1969. Principles of Path Analysis. In Edgar F. Borgatta (editor). Sociological Methodology, San Francisco: Jossey-Bass Behavioral Science.

Michael R. Dove. 1985. Peranan Kebudayaan Tradisional Indonesia dalam Modernisasi. Jakarta :Yayasan Obor Indonesia.

Mosher A.T. .1966. Menggerakan dan Membangun Pertanian (Terjemahan). Jakarta : Yasaguna.

Paturochman, Maman. 2012. Penentuan Jumlah dan Teknik Pengambilan Sampel. Bandung: Fakultas Peternakan Univ. Padjadjaran.

Petebang, Edi. 1999. Ketergantungan Masyarakat Dayak Terhadap Hutan. Jurnal Antropologi Sosial. Volume 93. Nomor 3.

Riduwan, 2008. Cara Menggunakan dan Memaknai Analisis Jalur (Path Analysis). Bandung: Alfabeta.

Rogers, EM, and FF. Shoemaker. 1971. Communication of Innovation. Newyork : Free Press.

Suandi dan Damayanti, Yusma. 2010. Analisis Disparitas Kesejahteraan Ekonomi Subjektif Keluarga Petani di Daerah Perdesaan Provinsi Jambi Berdasarkan Agroekologi Wilayah. Jurnal Unijam. Volume 12. Nomor 1. Universitas Jambi. 


\section{AIMBAR \\ Agribisnis \\ ISSN 2460-4321}

Volume 1・Nomor 1・Juli 2015

Sudjarwo .1997. Pola Interaksi Sosial Masyarakat Majemuk dalam Tiga Jalur Hubungan Sosial Untuk Mencapai Integrasi Bangsa. Disertasi Doktor, Pascasarjana, Universitas, Padjadjaran. (Tidak dipublikasikan).

Suharto, Edi, 2009. Kemiskinan dan Perlindungan Sosial di Indonesia. Bandung : Alfabeta.

Suharto, Edi, 2003. Kemiskinan dan Keberfungsian Sosial. Laporan Penelitian. Kerjasama LSP STKS dengan Pusat Penelitian dan Pengembangan UKS Balatbangsos.

Van den Ban, A. W, Hawkins, H.S. 1999. Penyuluhan Pertanian. Yogyakarta : Kanisius. 